\title{
A benign psoas mass following metal-on- metal resurfacing of the hip
}

\section{R. Boardman, F. R. Middleton, T. G. Kavanagh}

From Royal Surrey County Hospital, Guildford and St Helier Hospital, Carshalton, Surrey, England

D. R. Boardman, MRCS, SpR Orthopaedics F. R. Middleton, MRCS, SpR Orthopaedics Royal Surrey County Hospital, Egerton Road, Guildford, Surrey GU2 7XX, UK.

T. G. Kavanagh, FRCS, Consultant Orthopaedic Surgeon

St Helier Hospital, Wrythe Lane, Carshalton, Surrey SM5 1AA, UK.

Correspondence should be sent to Mr D. R. Boardman; e-mail: DavidBoardman@ doctors.net.uk

(C2006 British Editorial Society of Bone and Joint Surgery doi:10.1302/0301-620X.88B3. $16748 \$ 2.00$

$J$ Bone Joint Surg $[\mathrm{Br}]$ 2006;88-B:402-4.

Received 18 May 2005 Accepted after revision 12 October 2005

\begin{abstract}
As metal-on-metal arthroplasty becomes more widespread, concerns are being raised about the potential dangers of metal particulate debris. We present the case of a benign psoas mass secondary to the presence of such particles. The mass was excised and the hip resurfacing subsequently revised to a total hip replacement.
\end{abstract}

Metal-on-metal hip resurfacing is a commonly used option in younger, active patients. However, despite encouraging early results, ${ }^{1}$ there is concern about its long-term safety, as high concentrations of metal ions are released into the surrounding tissues, the bloodstream and the lymphatics. ${ }^{2}$ Lymphocytic perivascular infiltration may be seen around metal-on-metal joint replacements, more extensive around prostheses with aseptic loosening than in well fixed components. ${ }^{3}$ This may be part of a novel, clinically significant and immunologically mediated mode of failure secondary to high concentrations of nanometre-sized metal debris. We describe a patient who developed a benign psoas mass secondary to wear particles from a metal-on-metal resurfacing arthroplasty. Excision of the mass was required and subsequently a revision procedure.

\section{Case report}

A 61-year-old woman, with no history of metal hypersensitivity, underwent a resurfacing arthroplasty (Midland Medical Technologies, Birmingham, UK) for osteoarthritis of the right hip. Magnetic resonance imaging (MRI) 14 months earlier had excluded spinal pathology and confirmed arthritis of the hip (Fig. 1a). She made an unremarkable post-operative recovery and was asymptomatic after six months. However, one month later, she returned with increasing pain in the right hip and buttock. The inflammatory markers, plain radiographs and bone scans were normal and observation was continued.

Two years after the arthroplasty she noticed a mass in the right iliac fossa. Computerised tomography (CT) showed a solid, circumscribed heterogeneous lesion around the femoral neck and proximal femur, involving the psoas tendon and passing into the right hemipelvis at the sacral promontory (Fig. 1b). The appearances were of a malignant soft-tissue tumour which had not been present on the preoperative MRI scans (Fig. 1a).

The mass was excised 32 months after the resurfacing procedure. At operation a necrotic mass with some liquefaction was seen within the psoas, extending below the inguinal ligament. Microscopy showed areas of dense fibrous tissue with lymphocytic aggregates, necrotic muscle and undefined necrosis. Mass spectrometry confirmed high concentrations of chromium (122 $\mu \mathrm{g} / \mathrm{g}$; normal 0.005 to $0.18 \mu \mathrm{g} /$ $\mathrm{g})^{4}$ and cobalt $(277 \mu \mathrm{g} / \mathrm{g}$; normal 0.006 to 0.24 $\mu \mathrm{g} / \mathrm{g})$ in the excised tissue. ${ }^{4,5}$

The pain persisted and 4.5 years after resurfacing the implant was revised to a ceramic-onceramic total hip replacement. At operation, synovitis was noted and the femoral neck was invaded by dark staining material which could be traced to the psoas tendon. Both acetabular and femoral components were well fixed. Histology of the synovium and the insertion of the psoas tendon showed areas of fibrous tissue with dense infiltration of lymphocytes, giant cells and histiocytes. The resected femoral head was covered by necrotic tissue which included abundant histiocytes containing metal debris; the formation of lymphoid follicles in the adjacent bone marrow was also noted. Laboratory analysis of the retrieved components showed that the rates of linear wear of the acetabular (5.1 $\mu \mathrm{m} /$ year) and femoral components (1.6 $\mu \mathrm{m} /$ year) were within normal limits. After the revision the pain resolved.

\section{Discussion}

The increased use of metal-on-metal arthroplasty has renewed concern regarding the long- 


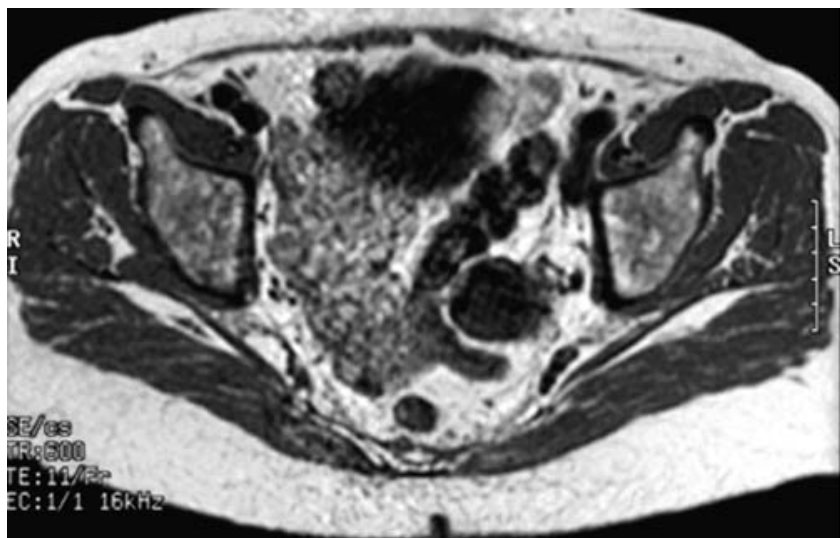

Fig. 1a

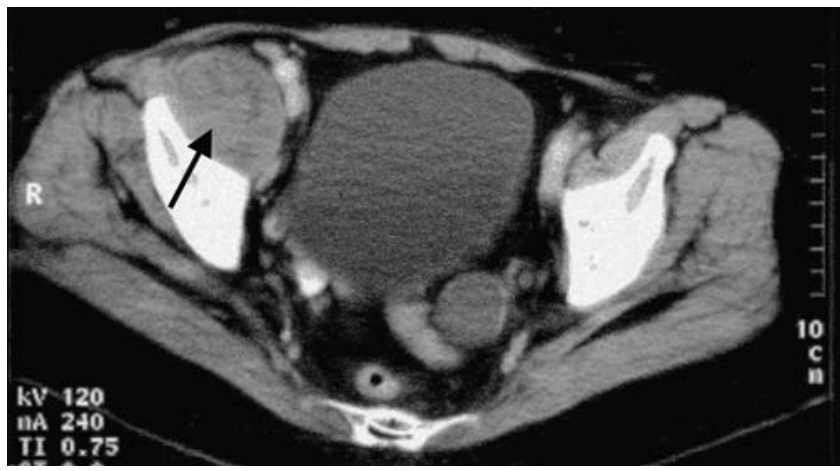

Fig. 1b

Figure 1a-Pre-operative MRI scan. There is no evidence of a right psoas mass. Figure $1 \mathrm{~b}-\mathrm{CT}$ image confirming a right psoas mass 27 months after resurfacing arthroplasty of the right hip.

term consequences of exposure to metallic particulate debris. It is suggested that degradation products from orthopaedic implants, in the form of metal-protein complexes, inorganic metal salts and free metal ions, may be associated with adverse responses in local and remote tissues. ${ }^{6,7}$ High concentrations of metal ions have been seen at post-mortem in the lymph nodes and bone marrow of patients with worn metal-on-metal hip replacements. ${ }^{8}$ Elevated concentrations of metal in the serum and urine have been demonstrated in patients with metal-on-metal total hip replacements during the life of the implant. ${ }^{9}$ It has been suggested that this exposure may promote malignant change in the reticuloendothelial system ${ }^{2}$ as malignancies have been associated with cobalt and chromium implants in animal models. ${ }^{10,11}$ As metal-on-metal arthroplasty is used mainly in younger patients such concerns are particularly relevant.

The development of malignant tumours after total joint replacement using metal on polyethylene is rare, with only 26 sarcomas reported between 1984 and 2001. This low incidence compared with number of arthroplasties is quoted as evidence against a causal relationship. ${ }^{12}$ The observed variation in the incidence of different forms of cancer in patients with total hip replacements compared with the general population also suggests that factors other than hip replacement play a major role in the aetiology of cancer. $^{13}$

The wear particles produced by metal-on-metal bearings are an order of magnitude smaller than those from metal on polyethylene. ${ }^{14}$ Therefore, although the volumetric wear of metal-on-metal articulations is less than that of metal on polyethylene, the surface area of the debris is far greater. These nanometer-sized particles appear to stimulate a lymphocytic response involving macrophages laden with metal particles which is not seen after the use of metal-on-polyethylene joints. It is suggested that the early failure of some metal-on-metal articulations may be immunologically mediated, involving lymphocyte activation. ${ }^{3}$

Histological specimens taken from our patient at revision arthroplasty showed dense lymphocytic infiltration with areas of necrosis. Although similar findings have been reported in peri-prosthetic tissues containing cobalt/chromium particles, ${ }^{3,8}$ migration to psoas is a new finding. It is recognised that concentrations of cobalt and chromium in the serum increase after successful metal-on-metal hip arthroplasty in asymptomatic patients. ${ }^{15}$ However, the highest concentrations in these patients were much lower (cobalt $44 \mathrm{nmol} / \mathrm{l}$, chromium $165 \mathrm{nmol} / \mathrm{l}$ ) than those in the psoas mass reported here.

To our knowledge, the development of a pelvic mass after metal-on-metal total hip replacement or resurfacing arthroplasty has not so far been reported. An intra-pelvic synovial cyst, secondary to wear particles from a loose, cemented Mckee-Farrar total hip replacement, has been described. ${ }^{16}$ The cyst, communicating through a defect in the acetabular floor, was filled with metallic and cement debris. However, it was separate from psoas and there was no muscle necrosis as in our case.

Dissemination of metallic wear particles to distant organs can affect the liver, spleen and lymph nodes via a macrophage-mediated response. In severe cases clinically significant granulomata may form in the liver and spleen, with necrosis in affected lymph nodes. ${ }^{17}$ The mass we describe appears to have developed via an alternative immunological mechanism which produces dense lymphocytic aggregations. We propose that the mass arose through the migration of nanometer-sized metallic wear particles along the psoas tendon into muscle resulting in ischaemic necrosis, secondary to lymphocyte-mediated vasculitis.

This case highlights the extent of the possible response to wear particles from metal-on-metal articulations. Although there was no evidence of malignancy, we suggest that the use of such implants should continue to be monitored closely.

No benefits in any form have been received or will be received from a commercial party related directly or indirectly to the subject of this article.

\section{References}

1. Daniel J, Pynsent PB, McMinn DJ. Metal-on-metal resurfacing of the hip in patients under the age of 55 years with osteoarthritis. J Bone Joint Surg [Br] 2004; 86-B:177-84. 
2. Case CP, Langkamer VG, James C, et al. Widespread dissemination of metal debris from implants. J Bone Joint Surg [Br] 1994;76-B:701-12.

3. Davies AP, Willert HG, Campbell PA, Learmonth ID, Case CP. An unusual lymphocytic perivascular infiltration in tissues around contemporary metal-on-metal joint replacements. J Bone Joint Surg [Am] 2005;87-A:18-27.

4. Iyengar GV, Kollmer WE, Bowen HJM. The elemental composition of human tissues and body fluids: a compilation of values for adults. Verlag Chemie Weinheim: Germany, 1978:80-3.

5. Schroeder HA, Nason AP, Tipton IH. Essential trace metal in man: cobalt. J Chron Dis 1967;20:869-90.

6. Hallab NJ, Jacobs JJ, Skipor A, et al. Systematic metal-protein binding associated with total joint replacement arthroplasty. J Biomed Mater Res 2000;49:353-61.

7. Jacobs JJ, Gilbert JL, Urban RM. Corrosion of metal orthopaedic implants. J Bone Joint Surg [Am] 1998;80-A:268-82.

8. Doorn PF, Mirra JM, Campbell PA, Amstutz HC. Tissue reaction to metal on metal total hip prostheses. Clin Orthop 1996;329(Suppl):187-205

9. Jacobs JJ, Hallab NJ, Skipor AK, Urban RM. Metal degradation products: a cause for concern in metal-metal bearings? Clin Orthop 2003;417:139-47.
10. Heath JC, Freeman MA, Swanson SA. Carcinogenic properties of wear particles from prostheses made in cobalt-chromium alloy. Lancet 1971;1:564-6.

11. Howie DW, Rogers SD, McGee MA, Haynes DR. Biologic effects of cobalt chrome in cell and animal models. Clin Orthop 1996;329(Suppl):217-32.

12. Lucas DR, Miller PR, Mott MP, Kronick JL, Unni KK. Arthroplasty-associated malignant fibrous histiocytoma: two case reports. Histopathology 2001;39:620-8.

13. Visuri T, Pukkala E, Paavolainen $P$, Pulkkinen $P$, Riska EB. Cancer risk after metal on metal and polyethylene on metal total hip arthroplasty. Clin Orthop 1996;329(Suppl):280-9.

14. Margevicius KJ, Bauer TW, McMahon JT, Brown SA, Merritt K. Isolation and characterization of debris in membranes around total joint prostheses. J Bone Joint Surg [Am] 1994;76-A:1664-75.

15. Clarke MT, Lee PT, Arora A, Villar RN. Levels of metal ions after small- and largediameter metal-on-metal hip arthroplasty. J Bone Joint Surg [Br] 2003;85-B:913-17.

16. Madan S, Jowett RL, Goodwin MI. Recurrent intrapelvic cyst complicating metalon-metal cemented total hip arthroplasty. Arch Orthop Trauma Surg 2000;120:508-10.

17. Urban RM, Jacobs JJ, Tomlinson MJ, et al. Dissemination of wear particles to the liver, spleen and abdominal lymph nodes of patients with hip or knee replacement. J Bone Joint Surg [Am] 2000;82-A:457-76. 